MaPan : Jurnal Matematika dan Pembelajaran

p-ISSN: 2354-6883 ; e-ISSN: 2581-172X

Volume 9, No 2, Dec 2021 (242-259)

DOI: https://doi.org/10.24252/mapan.2020v8n2a4

\title{
DEVELOPING DIGITAL MODULE USING FLIP PDF PROFESSIONAL TO FACILITATE STUDENTS' MATHEMATICAL COMMUNICATION SKILLS ON NUMBER PATTERN MATERIAL
}

\author{
Sinta Dwi Lestari ${ }^{1)}$, Palupi Sri Wijayanti2)* \\ 1,2Department of Mathematics Education, Universitas PGRI Yogyakarta \\ 1,2J1. PGRI I Sonosewu No. 117 Yogyakarta 55182, Indonesia \\ Email: shintadewilestari09@gmail.com¹), palupi@upy.ac.id2)
}

Received November 22, 2021; Revised December 26, 2021; Accepted December 26, 2021

\begin{abstract}
:
This study aims to develop a digital module using Flip PDF Professional to facilitate students' mathematical communication skills through contextual problems. This research is Research \& Development (R\&D). The development model used is the ADDIE development model. The stages in the development model are analysis, design, development, implementation, and evaluation. The digital module was piloted to class VIII A MTs Al Ichsan students for the 2020/2021 academic year. The module was compiled to meet the valid, practical, and effective criteria. Based on the results of the study, it was obtained that (1) The digital module is declared "valid" with an average expert score of $88 \%$ with the "excellent" criteria. (2) The digital module is declared "practical" with an average score percentage of $90 \%$ with the "excellent" criteria. (3) The digital module is declared "effective" with an average score percentage of $88 \%$ with the "excellent" criteria. The analysis results of the effectiveness of the digital module to facilitate mathematical communication skills show that the average test results of students are more than the minimum completeness criteria. This module can be further developed by other researchers discussing different materials or made even more exciting and developed using other application assistance.
\end{abstract}

Keywords: Flip PDF, Mathematical Communication, Module

\section{PENGEMBANGAN MODUL DIGITAL MENGGUNAKAN FLIP PDF PROFESSIONAL UNTUK MEMFASILITASI KEMAMPUAN KOMUNIKASI MATEMATIS SISWA PADA MATERI POLA BILANGAN}

\begin{abstract}
Abstrak:
Penelitian ini bertujuan untuk mengembangkan modul digital menggunakan Flip PDF Professional yang dikembangkan dalam rangka memfasilitasi kemampuan komunikasi matematis siswa melalui permasalahan kontekstual. Penelitian ini adalah Research \& Development (R\&D). Model pengembangan yang digunakan yaitu model pengembangan ADDIE. Adapun tahapan dalam model pengembangan tersebut yaitu: analysis (analisis), design (desain), development (pengembangan), implementation (implementasi), dan evaluation (evaluasi). Modul digital
\end{abstract}


diujicobakan kepada siswa kelas VIII A MTs Al Ichsan tahun ajaran 2020/2021. Modul yang disusun memenuhi kriteria valid, praktis, dam efektif. Berdasarkan hasil penelitian diperoleh: (1) Modul digital dinyatakan "valid" dengan persentase skor rata-rata ahli sebesar 88\% dengan kriteria "sangat baik". (2) Modul digital dinyatakan "praktis" dengan persentase skor rata-rata sebesar 90\% dengan kriteria "sangat baik". (3) Modul digital dinyatakan "efektif" dengan persentase skor rata-rata sebesar $88 \%$ dengan kriteria "sangat baik". Hasil analisis keefektifan modul digital untuk memfasilitasi kemampuan komunikasi matematis menunjukan hasil rata-rata tes siswa lebih dari keriteria ketuntasan minimum. Modul ini dapat dikembangkan lagi oleh peneliti selanjutnya dengan pembahasan materi yang berbeda atau dapat dibuat dengan lebih menarik lagi dan dapat juga dikembangkan dengan menggunakan bantuan aplikasi yang berbeda.

Kata Kunci: Flip PDF, Komunikasi Matematis, Modul

How to Cite: Lestari, S. D., \& Wijayanti, P. S. (2021). Developing Digital Module Using Flip Pdf Professional to Facilitate Students' Mathematical Communication Skills on Number Pattern Material. MaPan : Jurnal Matematika dan Pembelajaran, 9(2), 242-259. https:/ / doi.org/10.24252/mapan.2021v9n2a4.

\section{INTRODUCTION}

I

n line with the advancement of science and technology, an educator must be able to keep up with the times so as not to be left behind (Akarim, 2020). Therefore, an educator must also be able to create and design learning media so that learning media must be used as effectively as possible (Fakhrurrazi, 2018). That way, educators must design learning media as attractive as possible to attract students' interest in learning mathematics, so students pay more attention to learning and do not feel bored.

Digital module-based learning media is one of the learning media designed and created to learn mathematics in the era of development with the current advances in science and technology, especially in facilitating students' mathematical communication skills (Hamid, Ramadhani, Masrul, Juliana, Safitri, Munsarif, \& Simarmata, 2020). There is much software that supports the creation of digital modules and interactive digital modules. The software used to create digital modules are Adobe PDF, Sigil, ePUB, and Kvisoft Flipbook Maker Pro, while the software used to create interactive digital modules are Flipbook Maker, FlipHTML5, Adobe Flash Player, Lectora Inspire, 3D PageFlip, and Flip PDF. Professional. In order to attract students' 
attention to stay focused on learning, it is better if the module is made to be interactive and innovative (Winatha, Suharsono, \& Agustini, 2018).

The advantages of Flip PDF Professional are that it can add multimedia features such as videos, music, images, hyperlinks, and others. In the form of a flipbook, the operation is effortless and can be exported in various formats, namely exe, html, fbr, and app. However, Flip PDF Professional also has drawbacks, namely that it can only be processed from files in PDF format, if there are changes or errors in the main file, a new project must be created, and the file size is quite large because the contents of the digital module are added with various media features such as video, music, images, hyperlinks, and others (Yunianto, Negara, \& Suherman, 2019). Judging from the advantages and disadvantages of Flip PDF Professional, the software can be used to develop interactive, innovative, and effective digital modules. Flip PDF Professional can also combine several media, both audio and visual.

Digital module using Flip PDF Professional can make students interactive in learning it, so it is expected to facilitate student learning (Herawati \& Muhtadi, 2018). Digital module using Flip PDF Professional can also be accessed online via a link. Digital modules using Flip PDF Professional can be accessed on electronic devices and can even be accessed using cellphones or other electronic media so that students can access learning media without being fixated on space and time because students can learn the material in digital modules using Flip PDF Professional anytime and anywhere. It is expected that learning using digital modules will make learning efficient and provide learning facilities for students, thus facilitating learning.

Digital module using Flip PDF Professional is also used as a self-study resource. The digital module using interactive and innovative Flip PDF Professional can provide easy learning for students, especially facilitating students' mathematical communication skills. According to Ranti (2015), mathematical communication skills, based on the recommendations of The National Council of Teachers of Mathematics (NCTM), are: (1) connecting contextual problems with mathematical ideas, (2) explaining ideas or ideas from contextual problems both orally and in writing, (3) expressing an image or contextual problem into a mathematical idea, and (4) reveal a description or conclusion orally or in writing.

In addition, mathematical communication is also one of the social activities (talking) and as a thinking tool (writing) which is recommended by 
experts so that it continues to be developed among students (Umar, 2012). Mathematical communication skills are the ability to convey mathematical ideas, both orally and in writing as well as the ability to understand and accept other people's mathematical ideas/ideas carefully, analytically, critically, and evaluatively to sharpen understanding (Lestari \& Yudhanegara, 2015). Mathematical communication needs to be considered in learning mathematics because through communication, and students can build and develop their mathematical thinking.

Based on research conducted by Hodiyanto, Darma, and Putra (2020), students' mathematical communication skills can be developed through learning processes at school, one of which is learning mathematics. This happens because one of the elements of mathematics is the science of logic, which can develop students' thinking skills. Thus, mathematics has an essential role in developing mathematical communication skills. In order to develop mathematical communication skills, educators must be able to develop learning media by the times (Ashim, Asikin, Kharisudin, \& Wardono, 2019), where learning media is essential to help students understand learning (Miftah, 2013).

The results of an interview conducted on May 21, 2021, with the teacher who teaches mathematics in class VIII at MTs Al Ichsan show that mathematics is considered a difficult subject and is a scourge for students, causing students to be less enthusiastic in participating in the learning process that takes place in class. Lack of students' mathematical communication skills will impact student learning outcomes, so that students cannot build and develop their mathematical communication skills (Puji, Nizaruddin, \& Endahwuri, 2020). Consequently, the learning outcomes obtained by students also do not meet the Minimum Completeness Criteria that the school has determined.

In the learning process, the teacher only uses learning media in textbooks, worksheets, and other sources from the internet, making students feel bored and less interested in reading or studying learning materials. In the learning process, the teacher still uses a contextual approach because it is constrained by the lack of students' mathematical communication skills in expressing their opinions, and students are also still hesitant to express their opinions. Based on the interviews with class VIII MTs Al Ichsan teachers, it was felt that the digital module could help facilitate interest in learning and students' mathematical communication skills. With the module's appearance 
made as attractive as possible, there are interesting illustrations, videos, and colorful designs so that students will not feel bored when reading them. Submission of material related to contextual problems is felt to help students understand the learning material more easily.

Students in class VIII at MTs Al Ichsan had never used a digital mathematics module in their previous learning so that learning using digital mathematics modules in future learning will make students interested in the mathematics learning process. The display modules and illustrations are presented attractively. The presentation of learning videos and contextual problems and using language that is easy to understand will make students not feel bored to read and study digital mathematics modules and make students more enthusiastic in learning mathematics so that digital mathematics modules can make learning math not boring.

Based on this idea, this study selected digital mathematics module teaching materials using Flip PDF Professional to facilitate students learning mathematics. The digital mathematics module with various elements including text, images, photos, videos, animations, and attractive designs will make students interested in learning it, and students are also more interactive in studying this digital module. That way, students will not feel bored, so that students can facilitate their mathematical communication skills.

Learning activities using digital modules are expected to facilitate students' mathematical communication skills in mathematics learning and not be boring in the ongoing learning process. This digital module makes it easier for students to understand the material and explore it anytime and anywhere. Because students can also access digital modules via cellphones or other electronic media, so students do not have to bring books every time students want to learn the material. Thus, it is expected to achieve maximum results in learning outcomes.

\section{METHODS}

This research is Research and Development ( $\&$ \&), a research method used to research, design, produce certain products and test the effectiveness of the products (Sugiyono, 2019). The development model used in this study is the ADDIE development model, consisting of five stages: Analysis, Design, Development, Implementation, and Evaluation (Sari, 2017). 


\section{Analysis}

At this stage, an analysis of the needs, curriculum, character of students, and the selection of the types of teaching materials that will be developed is carried out through interviews with mathematics teachers.

a. Needs Analysis

Need analysis includes analyzing learning needs and problems in mathematics, namely learning resources, relevant materials, strategies, learning models, conditions, and student learning outcomes.

b. Curriculum Analysis

Curriculum analysis includes analysis of Core Competencies (KI), Basic Competencies (KD), and Competency Achievement Indicators (GPA). This stage aims to determine the standards students must achieve after studying the material using the developed digital module.

c. Analysis of Student Characteristics

Student characteristics were analyzed to determine the characteristics of class VIII MTs Al Ichsan students. At this stage, interviews with teachers and learning observations were conducted. The analysis results are used as guidelines for compiling and developing digital modules.

\section{Design}

In the design stage is the product design stage as needed, which is a follow-up stage after obtaining information based on the analysis that has been carried out at the analysis stage.

a. Determining learning materials

b. Prewriting

c. Digital module framework

1) Specifying the digital module tittle

2) Digital module writing

a) Formulating basic competencies

b) Formulating indicators of competency achievement

c) Formulating learning objectives

d) Determine the assessment or evaluation tool

e) Design of the preparation of digital module with aspects of mathematical communication skills

f) Arrange material

g) Digital module structure 
d. Preparation of research instruments

1) Digital module assessment instrument

2) Question response of educators and students

3) Mathematical communication skills test

\section{Development}

The development is carried out by collecting material sources, reference images, compiling modules, and developing digital modules using Flip PDF Professional. At this stage, improvements are made to the digital module product that has been designed in accordance with the module preparation procedure that has been prepared. The product made is then consulted with the supervisor to be then validated by media experts and material experts. Product improvement is based on the validation results of media experts and material experts in accordance with the criteria stated in the assessment instrument. The validation results will later become a reference for improvement used for product revision.

\section{Implementation}

At this stage, small-scale trials and large-scale trials are carried out. Small-scale trials were conducted to 6 students of class VIII B, while large-scale trials were conducted to students of class VIII A at MTs Al Ichsan. Teachers and students are asked to fill out a response questionnaire to the developed digital module at this stage. In addition, observation of the implementation of learning by teachers and students is carried out by observers during the learning process. Then students are given a test of mathematical communication skills to determine the effectiveness of the developed digital module.

The results of the practicality test were obtained from the teacher's response questionnaire and observations of the learning implementation by the teacher. Also, the effectiveness test results were obtained from student response questionnaires, observations of the implementation of learning by students, and the post-test results of mathematical communication skills.

\section{Evaluation}

At this stage, an analysis of the quality of the digital module is carried out based on textbook standards by the National Education Standards Agency (BSNP) (Pramesti, 2017). Analysis of the quality of the developed digital module in terms of validity, practicality, and effectiveness. The evaluation is carried out by analyzing the shortcomings during product trials and then revising these deficiencies to determine the quality of the digital module. $\mathrm{A}$ 
digital module can be said to be of high quality if it meets the criteria of being valid, practical, and effective. The development flow of the ADDIE model used in this study is shown in figure 1.

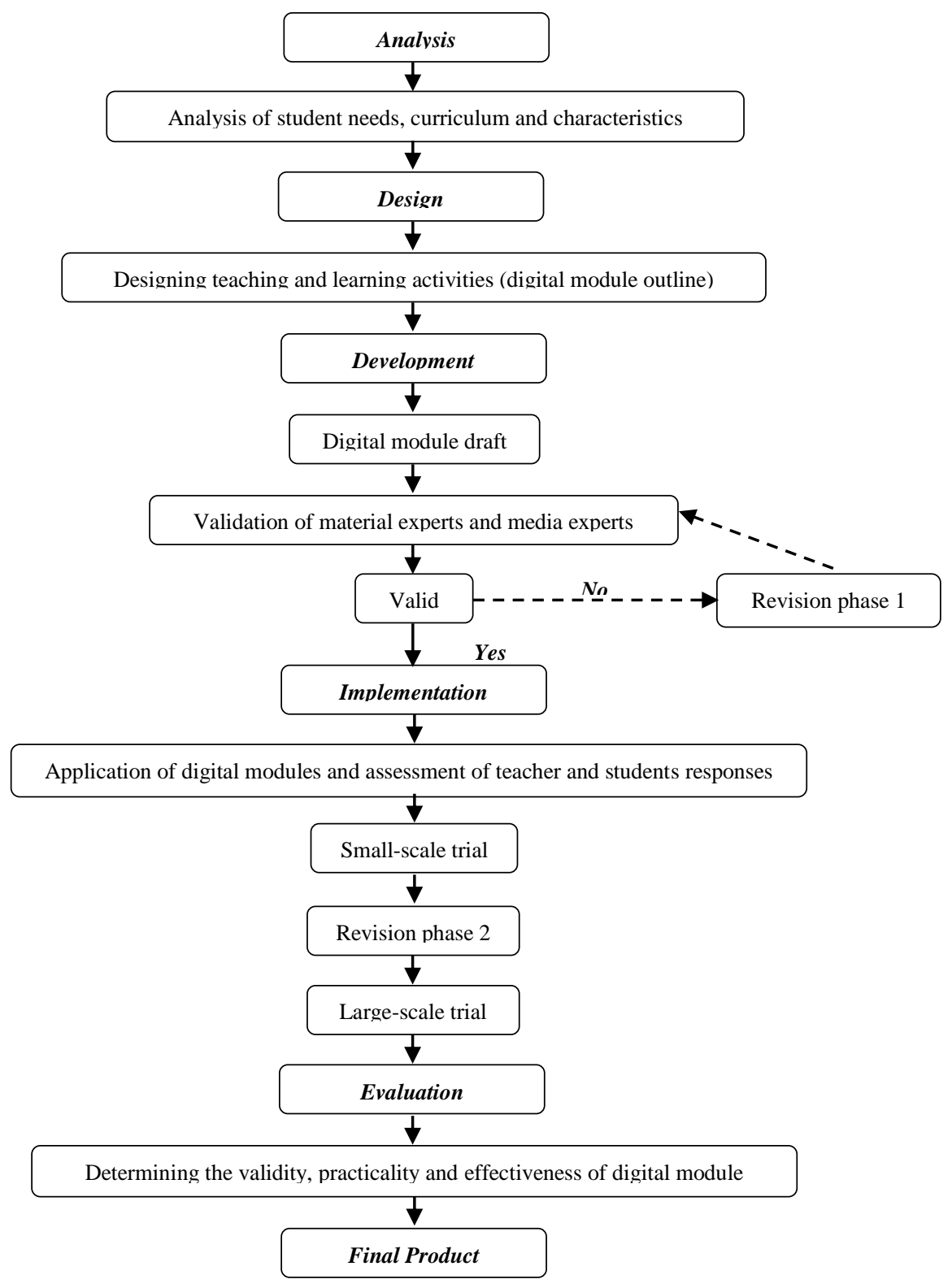

Figure 1. Development Flow of ADDIE Model

This study uses qualitative data from the questionnaire sheet in the form of a review of comments or suggestions from validation experts and teacher and student questionnaire sheets in small-scale trials. The results of the study are to perfect the developed digital module. The quantitative data are validation assessment results by material and media experts, teacher and 
student response questionnaire sheets, learning implementation observation sheets, and students' mathematical communication ability test results after using the developed digital module.

The validation sheet and response questionnaire were analyzed using a Likert Scale, calculating the average value, the range of scores obtained from the average value, and the average percentage result, which was then interpreted in the form of a percentage of interpretation criteria (Wirda, Rosni, Berutu, \& Rahmad, 2018).

The results of the effectiveness of the mathematical communication ability test use the calculation of the minimum completeness criteria, which means that students have reached the minimum completeness criteria of the maximum expected value (Arikunto, 2018). The percentage of minimum completeness criteria is calculated from the overall student score, which is then interpreted as a percentage of the interpretation criteria. The following is the calculation of the effectiveness results using the minimum completeness criteria, shown in table 1.

Table 1. Range Score Minimum Completeness Criteria

\begin{tabular}{cc}
\hline Score $(\boldsymbol{N S})$ & Criteria \\
\hline $\mathbf{8 5}<\boldsymbol{N} \boldsymbol{S} \leq \mathbf{1 0 0}$ & Very Good/A \\
$\mathbf{7 5}<\boldsymbol{N} \boldsymbol{S} \leq \mathbf{8 5}$ & Good/B \\
$\mathbf{5 5}<\boldsymbol{N} \boldsymbol{S} \leq \mathbf{7 5}$ & Fair/C \\
$\mathbf{3 5}<\boldsymbol{N} \boldsymbol{S} \leq \mathbf{5 5}$ & Poor/D \\
$\mathbf{0}<\boldsymbol{N} \boldsymbol{S} \leq \mathbf{3 5}$ & Very Poor $/ \mathrm{E}$ \\
\hline & (Widoyoko, 2019)
\end{tabular}

The following is a table of score intervals and the percentage of interpretation criteria, shown in table 2.

Table 2. Scoring Range Interpretation Criteria

\begin{tabular}{ccc}
\hline Score Interval & Score Range & Criteria \\
\hline $\boldsymbol{X}>\overline{\boldsymbol{X}}_{\boldsymbol{i}}+\mathbf{1 . 8} \times \boldsymbol{s} \boldsymbol{b}_{\boldsymbol{i}}$ & $X>3.4$ & Very Good \\
$\overline{\boldsymbol{X}}_{\boldsymbol{i}}+\mathbf{0 . 6} \times \boldsymbol{s} \boldsymbol{b}_{\boldsymbol{i}}<\boldsymbol{X} \leq \overline{\boldsymbol{X}}_{\boldsymbol{i}}+\mathbf{1 . 8} \times \boldsymbol{s} \boldsymbol{b}_{\boldsymbol{i}}$ & $2.8<X \leq 3.4$ & Good \\
$\overline{\boldsymbol{X}}_{\boldsymbol{i}}-\mathbf{0 . 6} \times \boldsymbol{s} \boldsymbol{b}_{\boldsymbol{i}}<\boldsymbol{X} \leq \overline{\boldsymbol{X}}_{\boldsymbol{i}}+\mathbf{0 . 6} \times \boldsymbol{s} \boldsymbol{b}_{\boldsymbol{i}}$ & $2.2<X \leq 2.8$ & Fair \\
$\overline{\boldsymbol{X}}_{\boldsymbol{i}}-\mathbf{1 . 8} \times \boldsymbol{s} \boldsymbol{b}_{\boldsymbol{i}}<\boldsymbol{X} \leq \overline{\boldsymbol{X}}_{\boldsymbol{i}}-\mathbf{0 . 6} \times \boldsymbol{s} \boldsymbol{b}_{\boldsymbol{i}}$ & $1.6<X \leq 2.2$ & Poor \\
$\boldsymbol{X} \leq \overline{\boldsymbol{X}}_{\boldsymbol{i}}-\mathbf{1 . 8} \times \boldsymbol{s} \boldsymbol{b}_{\boldsymbol{i}}$ & $X \leq 1.6$ & Very Poor \\
\hline & & (Widoyoko, 2019)
\end{tabular}




\section{RESULTS AND DISCUSSION}

\section{Analysis}

At the analysis stage, the researcher analyzed the needs, curriculum, student character, and the selection of teaching materials to be developed through interviews with the 8th-grade mathematics teacher at MTs Al Ichsan. Based on the needs analysis results, it is known that learning is still using the teacher-centered method or teacher-centered so that students are less active in the learning process. The teaching materials used in learning mathematics are textbooks, worksheets, and other internet sources so that it makes students feel bored and less interested in reading or studying learning materials. Therefore, it is necessary to use interesting teaching materials to facilitate students' abilities, one of which is digital modules. So based on the above analysis, the type of teaching material that will be developed is a digital module using Flip PDF Professional, which can facilitate students' mathematical communication skills in number pattern material.

\section{Design}

At the design stage, the researcher compiles the framework of the digital module and compiles the research instrument. At the stage of compiling the framework of the module, it is done by making an outline based on the results of the analysis, which starts from the (1) Introduction, consists of a cover page and supporting pages (preface and table of contents); (2) Contents, which consists of chapter I Introduction (background, brief description, core competencies, basic competencies and indicators of competency achievement, concept maps, biographies, learning objectives, and instructions for using digital modules), chapter II Activity 1 (determine the pattern of odd, even, square, rectangle, triangle, Pascal's triangle, and Fibonacci), chapter III Activity 2 (configuring objects from odd, even, square, rectangle, triangle, Pascal's triangle, and Fibonacci number patterns), chapter IV Summary, and chapter V Evaluation; and (3) Closing, consists of a glossary, answer key, author profile, bibliography, and closing page. In addition, the preparation of the research instrument is the digital module assessment instrument, teacher and student response questionnaires, and mathematical communication skills tests.

\section{Development}

In the development stage, the researcher develops the structure of the digital module from the outline designed at the design stage to become a complete digital module. After the outline has been created at the design stage, 
the next step is to change the outline format compiled in Microsoft Word 2013 and converted to PDF format. Then, it is converted to a digital module format using Flip PDF Professional software so that the final digital module created will be a file type .exe format that can be opened offline via mobile phones, computers, and other electronic devices. Several supporting software is also used in the digital module development stage, namely Icecream Screen Recorder and Corel Draw 2019. After the digital module is complete, the digital module and instruments are consulted with the supervisor for approval and then validated by material experts and media experts for comments or suggestions and writing as improvements to digital modules and instruments.

In this study, the validity of the module was seen from the results of the module validation questionnaire by media experts and material experts. The module validation questionnaire is adjusted to textbook standards by the National Education Standards Agency (BSNP) (Mahmud, 2016), namely by considering aspects of the feasibility of content, presentation of material, language, and graphics. The review results from experts in the form of comments or suggestions were used as a benchmark for making revisions to improve the digital modules developed. The results of the expert review are shown in table 3 , and the results of the digital module validation analysis by material experts and media experts are shown in table 4.

Table 3. Reviewer Result From Material Expert and Media Expert

\begin{tabular}{cl}
\hline Reviewer & \multicolumn{2}{c}{ Reviewer Result } \\
\hline & - The material presented does not show mathematical \\
Material & communication skills. \\
Expert & Less interactive module. \\
& - The problems presented do not show contextual problems. \\
& - There are still many mistakes in writing. \\
Media & - The background in the image is removed or adjusted to the \\
Expert & main background color.
\end{tabular}

Table 4. Results of Validity Analysis by Material Experts and Media Experts

\begin{tabular}{lccc}
\hline \multicolumn{1}{c}{ Total Score of Each Aspect } & Percentage & Criteria \\
\hline Material Expert Average & 3.77 & & \\
Media Expert Average & 3.28 & $88 \%$ & Excellent \\
Average of All Aspects of each Expert & 3.53 & & \\
$\quad$ Criteria & \multicolumn{2}{c}{ Excellent } \\
\hline
\end{tabular}


Based on the validation analysis results by material experts and media experts on the digital module, an average score of 3.53 out of a maximum score of 4 was obtained with the criteria of "excellent". From these results, it can be concluded that the digital module using Flip PDF Professional to facilitate students' mathematical communication skills on number pattern material is declared valid with the results of the percentage assessment of material experts and media experts, which is $88 \%$ and meets the "excellent" category or the digital module can be declared "valid". The results of several displays from the development of digital modules that have been developed can be seen in figure 2 and figure 3.

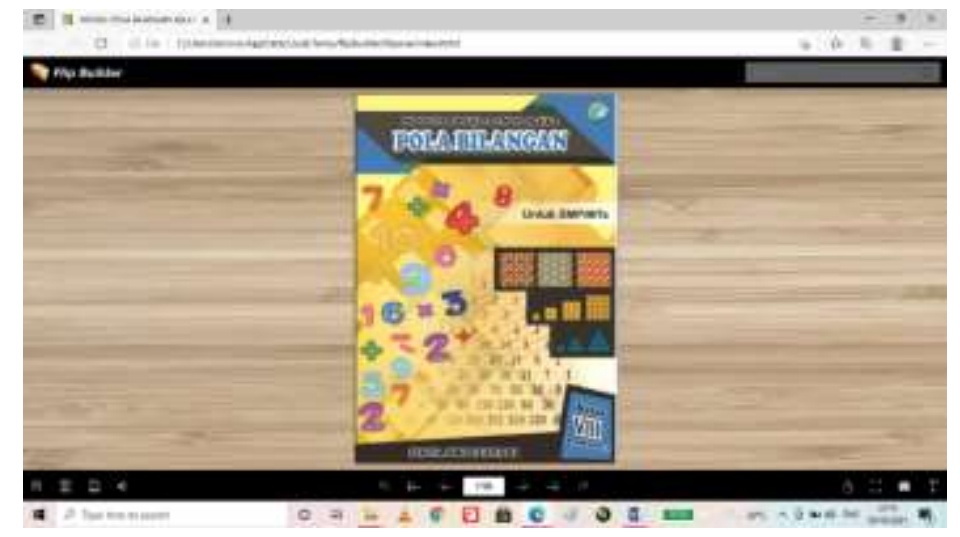

Figure 2. Cover Page of the Digital Module of Floating Result

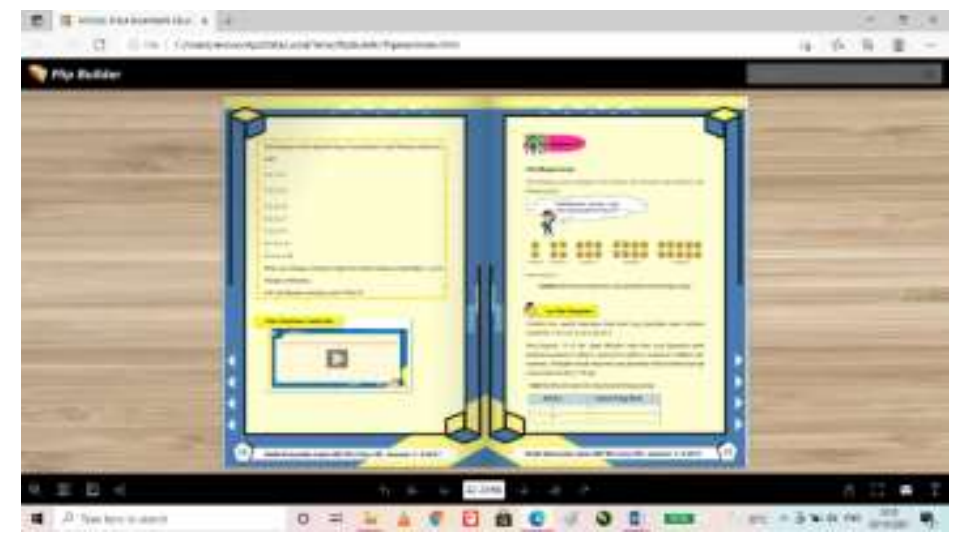

Figure 3. Material of Digital Module Development Result

\section{Implementation}

The implementation stage tests the developed digital modules, namely small-scale and large-scale trials. Small-scale trials were shown to 6 students of class VIII B, while large-scale trials were shown to students of class VIII A at Mts Al Ichsan. The small-scale trial aims to determine the assessment of the 
digital module that was developed before being tested in a large-scale test. Researchers received input or suggestions from teachers and students in smallscale trials to improve the digital module before being used in large-scale trials. Large-scale trials were conducted in 2 (two) offline meetings. The results of input or suggestions from teachers and students in small-scale trials can be seen in table 5.

Table 5. Feedback or Suggestions From Teacher and Students in Small-Scale Tests

\begin{tabular}{|c|c|}
\hline $\begin{array}{c}\text { Feedback or Suggestions From } \\
\text { Teacher }\end{array}$ & $\begin{array}{c}\text { Feedback or Suggestions From } \\
\text { Students }\end{array}$ \\
\hline $\begin{array}{l}\text { - There are still some misspellings } \\
\text { - Some pictures are not clear } \\
\text { - Instructions for using the module are } \\
\text { not clear }\end{array}$ & $\begin{array}{l}\text { - The module is very interesting and } \\
\text { helps in studying the material, but } \\
\text { in the table of contents, there is a } \\
\text { button that cannot go to the page I } \\
\text { want to go } \\
\text { - There are still some misspelled } \\
\text { words } \\
\text { - The module is very interesting, but } \\
\text { the instructions for using the } \\
\text { module are not clear }\end{array}$ \\
\hline
\end{tabular}

The results of the response questionnaire analysis by the teacher in the small-scale trial obtained an average total score of 3.42 by meeting the "good" criteria and the average percentage result of $86 \%$ by meeting the " excellent" criteria. However, the assessment on the language convenience aspect of the digital module is still below the overall average score of the aspects. Each indicator on the ease of language aspect of the digital module gets an average score of 3.33. There are still some writing errors, so a slight revision is needed before being tested on a large scale.

The results of the response questionnaire analysis by students in smallscale trials obtained an average total score of 3.61 by meeting the " excellent" criteria and the average percentage result of $90 \%$ by meeting the " excellent" criteria. However, the assessment on the presentation aspect of the digital module is still below the average value. This is because each indicator in the presentation aspect of the digital module gets an average score of 3.58. In addition, it is also because students still feel confused about the instructions for using the digital module, so a slight revision is needed before being tested on a large scale. 


\section{Evaluation}

At the evaluation stage, researchers analyzed the quality of the digital modules developed in terms of validity, practicality, and effectiveness. The results of the validity analysis can be seen at the development stage. The results of the practicality analysis were obtained from the teacher's response questionnaire sheet and the teacher's observation sheet on the implementation of learning. The results of the effectiveness analysis were obtained from student questionnaire sheets, student learning implementation sheets, and post-test results of students' mathematical communication skills. The results of the practicality analysis can be seen in table 6, and the results of the effectiveness analysis can be seen in table 8 .

Table 6. Practicality Analysis Results

\begin{tabular}{lcl}
\hline \multicolumn{1}{c}{ Practical Analysis } & Percentage & Criteria \\
\hline Teacher Response Questionnaire & $88 \%$ & Excellent \\
Teacher's Learning Implementation Observation Sheet & $92 \%$ & Excellent \\
Average & $90 \%$ & Excellent \\
\hline
\end{tabular}

Based on table 6, the results of the questionnaire analysis of teacher responses to the digital module obtained an average percentage of $88 \%$ with the "excellent" criteria. The results of the observation sheet analysis on the implementation of learning by the teacher obtained an average percentage of 92\% with the "excellent" criteria. So, the digital module is stated to be practical in facilitating students' mathematical communication skills.

The results of the effectiveness analysis obtained an average score of 84.46 indicators by meeting the criteria of " excellent ". The average score of the analysis of mathematical communication ability indicators shows that each student can understand each indicator of mathematical communication skills. However, the average score on indicator D, namely making conjectures, compiling arguments, formulating definitions and generalizations, is still below the average score of all indicators, with an average score of 64.76 . This is because in making conjectures, compiling arguments, formulating definitions and generalizations, some students do not write them down. Based on the analysis of the students' mathematical communication skills indicators, an average score of $84 \%$ was obtained by meeting the "excellent" criteria. The results of the effectiveness analysis of the mathematical communication skills test results are shown in table 7. 
Table 7. The Results of the Effectiveness Analysis of the Mathematical Communication Ability Test

\begin{tabular}{ccccc}
\hline Question Number & \multicolumn{4}{c}{ Indicator } \\
& A & B & C & D \\
\hline 1 & 65 & 65 & 83 & 51 \\
2 & 79 & 81 & 80 & 54 \\
3 & 79 & 78 & 77 & 55 \\
4 & 80 & 80 & 78 & 57 \\
5 & 66 & 78 & 78 & 55 \\
Average of Each Indicator & 87.86 & 90.95 & 94.29 & 64.76 \\
Percentage & $88 \%$ & $91 \%$ & $94 \%$ & $65 \%$ \\
Overall Average & \multicolumn{5}{c}{84,46} \\
Percentage & Excellent \\
Criteria & \multicolumn{5}{c}{}
\end{tabular}

Table 8. Effectiveness Analysis Result

\begin{tabular}{lcl}
\hline \multicolumn{1}{c}{ Practical Analysis } & Percentage & Criteria \\
\hline Student Response Questionnaire & $91 \%$ & Excellent \\
Student's Learning Implementation & $88 \%$ & Excellent \\
Observation Sheet & $84 \%$ & Excellent \\
Mathematical Communication Skills Test & $88 \%$ & Excellent \\
Average
\end{tabular}

Based on table 8 , the results of the questionnaire analysis of student responses to the digital module obtained an average percentage of $91 \%$ with the "excellent" criteria. The analysis results of the observation sheet on the implementation of learning by the teacher obtained an average percentage of $88 \%$ with the "excellent" criteria. The mathematical communication ability test results obtained an average of $84 \%$ with the "excellent" criteria. It can be concluded that the results of the effectiveness analysis obtained an average percentage of $88 \%$ with the "excellent" criteria. So, the digital module effectively facilitates students' mathematical communication skills.

\section{CONCLUSION}

Digital module using Flip PDF Professional has met valid, practical, and effective criteria. The developed digital module can facilitate students' mathematical communication skills by gaining knowledge through exposure to the material, contextual problems, videos, animations, and feedback that have been provided in the digital module independently. Learning using 
digital modules can attract students' attention so that students' learning motivation can increase, so the enthusiasm to develop other knowledge will also increase, including their mathematical communication skills.

The suggestions for developing these results are (1) Digital module developed is limited to number pattern material, making it possible for researchers to develop similar digital module with different materials; (2) Digital module developed using Flip PDF Professional software, making it possible for researchers to develop digital modules using other software; and (3) Digital modules can be developed even better by adding more interesting features such as moving animations or video explanations to make them even more interesting. The recommendations in this development are (1) students can know more about technology, and learning resources that can be accessed digitally, and (2) teachers can keep up with the times so as not to be left behind, teachers must also be able to create and design interesting learning media as possible in order to attract students' interest in learning.

\section{REFERENCES}

Akarim. (2020). Etika dalam pengembangan ilmu pengetahuan dan teknologi. Publikasi Ilmiah UMSU, 1(1), 1-16. Retrieved from http:// publikasiilmiah.umsu.ac.id/index.php/kumpulanmakalah/article/vie $\mathrm{w} / 921$.

Arikunto, S. (2018). Dasar-dasar evaluasi pendidikan. Jakarta: Bumi Aksara.

Ashim, M., Asikin, M., Kharisudin, I., \& Wardono. (2019). Perlunya komunikasi matematika dan mobile learning setting problem based learning untuk meningkatkan kemampuan 4C di era disrupsi. Jurnal Universitas Negeri Semarang, 2, 687-697. Retrieved from https:/ /journal. unnes.ac.id/sju/index.php/prisma/article/view/29239.

Fakhrurrazi. (2018). Hakikat pembelajaran yang efektif. jurnal IAIN Langsa, XI(1), 85-99. Retrieved from https://journal.iainlangsa.ac.id/index. php/at/article/view/529.

Hamid, M. A., Ramadhani, R., Masrul, Juliana, Safitri, M., Munsarif, M., \& Simarmata, J. (2020). Media pembelajaran. Medan: Yayasan Kita Menulis.

Herawati, N. S., \& Muhtadi, A. (2018). Pengembangan modul elektronik (emodul) interaktif pada mata pelajaran kimia kelas XI SMA. Jurnal Inovasi Teknologi Pendidikan, 5(2), 180-191. Retrieved from http:// journal.uny.ac.id/index.php/jitp.

Hodiyanto, Darma, Y., \& Putra, S. R. S. (2020). Pengembangan media pembelajaran berbasis macromedia flash bermuatan problem posing terhadap kemampuan pemecahan masalah matematis. Mosharafa Jurnal Pendidikan Matematika, 9, 323-334. Retrieved from https://journal. 
institutpendidikan.ac.id/index.php/mosharafa/article/view/mv9n2_1 3/587.

Lestari, K. E., \& Yudhanegara, M. R. (2015). Penelitian pendidikan metematika. Karawang: PT Refika Aditama.

Mahmud, Y. (2016). The appropriateness of 2013 curriculum english text book content based on content standard of BSNP : Student english book for the first semester of gradeXx of senior high school published by Ministry of Education and Culture (Walisongo State Islamic University). Retrieved from http:/ / eprints.walisongo.ac.id/6698/4/CHAPTER III.pdf.

Miftah, M. (2013). Fungsi dan peran media pembelajaran sebagai upaya peningkatan kemampuan belajar siswa. Jurnal Kwangsan, 95-105. Retrieved from https:/ / core.ac.uk/download/pdf/235523078.pdf.

Pramesti, S. L. D. (2017). Analisis materi dan penyajian buku teks matematika sebagai sumber belajar matematika. Jurnal Ilmiah Pendidikan Matematika, 5(1), 25-32. Retrieved from https://core.ac.uk/download/pdf/ 233939249.pdf.

Puji Astuti, E., Nizaruddin, N., \& Endahwuri, D. (2020). Efektifitas model pembelajaran numbered head tgether dan students teams achievement divisin berbantuan prezi terhadap kemampuan komunikasi matematis siswa SMA. IMAJINER Jurnal Matematika dan Pendidikan Matematika, 2. Retrieved from http://103.98.176.9/index.php/imajiner/article/view/ 5881.

Ranti, M. G. (2015). Meningkatkan kemampuan komunikasi matematis siswa menggunakan strategi writing to learn pada siswa SMP. Math Didactic: Jurnal Pendidikan Matematika, 1(2), 94-100. Retrieved from https:// core.ac.uk/download/pdf/295416359.pdf.

Sari, B. K. (2017). Desain pembelajaran model ADDIE dan implementasinya dengan teknik jigsaw. Universitas Muhammadiyah Sidoarjo, 87-102. Retrieved from http://eprints.umsida.ac.id/432/1/ARTIKEL Bintari Kartika Sari.pdf.

Sugiyono. (2019). Metode penelitian kualitatif, kuantitatif, dan RND. Bandung: Penerbit Alfabeta.

Umar, W. (2012). Membangun kemampuan komunikasi matematis dalam pembelajaran matematika. STKIP SILIWANGI Journal Infinity, 1(1), 1-9. Retrieved from http://e-journal.stkipsiliwangi.ac.id/index.php/ infinity/article/view/2.

Widoyoko, E. P. (2019). Evaluasi program pembelajaran. Yogyakarta: Pustaka Pelajar.

Winatha, K. R., Suharsono, N., \& Agustini, K. (2018). Pengembangan e-modul interaktif berbasis proyek mata pelajaran simulasi digital. Jurnal Pendidikan Teknologi dan Kejuruan, 15(2), 188-199. Retrieved from https:/ / ejournal.undiksha.ac.id/index.php/JPTK/article/view/14021. 
Wirda, M. A., Rosni;, Berutu, N., \& Rahmad, R. (2018). Pengembangan lembar kerja mahasiswa (LKM) berbasis project iata kuliah hasil belajar geografi TA 2017/2018. Jurnal Geografi, 10(2). Retrieved from https:// books.google.com/books?hl=id\&lr=\&id=Oip9DwAAQBAJ\&oi $=$ fnd $\& p g=P A 164 \& d q=L e m b a r+v a l i d a s i+d a n+l e m b a r+$ angket+respon + dianalisis+dengan+menggunakan+Skala+Likert\&ots=xhnj55rIO2\&sig= TjOF4jtpItc-uo4T0ygFo8zBhYM.

Yunianto, T., Negara, H. S., \& Suherman; (2019). Flip bilder: pengembangannya pada media pembelajaran matematika. TERAMPIL: Jurnal Pendidikan dan Pembelajaran Dasar, 115-127. Retrieved from http://103.88.229.8/index.php/terampil/article/view/5056. 